\title{
O acesso à informação no direito ambiental e a Convenção de Aarhus: a efetivação do direito fundamental à participação
}

\author{
Access to information on environmental law and the Aarhus Convention: the \\ realization of the fundamental right to participate
}

\author{
Jamile Bergamaschine Mata Diz \\ Ana Clara Gonçalves Discacciati**
}

\section{Resumo}

\begin{abstract}
O presente artigo tem por objetivo analisar a natureza do direito à informação como parte intrínseca e estruturante do direito de participação, a partir da consideração desse princípio como elemento fundamental para a promoção do desenvolvimento sustentável. Buscou-se também determinar o conteúdo da Convenção de Aarhus a partir de um marco normativo internacional que pretende efetivar a participação em questões ambientais de toda pessoa, física ou jurídica, pública ou privada, além de apresentar um caráter inovador no que tange às garantias de acesso à informação e participação em matéria ambiental. De forma a delimitar o alcance das medidas dispostas na referida Convenção, foi realizado um estudo de caso da abrangência e da interpretação que deve ser considerada pelos Estados signatários no momento da aplicação do instrumento, o qual foi interposto perante o Tribunal de Justiça da União Europeia, dado que todos os Estados-membros desse processo de integração tiveram que incorporar a Convenção de Aarhus como parte componente do Direito Comunitário.
\end{abstract}

Palavras-chave: Acesso à informação. Direito de participação. Convenção de Aarhus. União Europeia.

\section{Abstract}

This article aims to analyze the nature of the right to information as intrinsic and structuring part of the right to participate, from the consideration of this principle as a fundamental element in the promotion of sustainable development. It sought to determine the contents of the Aarhus Convention from an international legal framework that aims to effect participation in environmental issues to any person or entity, public or private, in addition to presenting an innovative character in relation to guarantees access to information and participation in environmental matters. In order to define the scope of the measures prepared in that Convention was held on case study precisely the scope and interpretation to be considered by the signatory States at the time of application of the instrument, having been brought before the Court of Justice of the European Union, as all member states of this integration process had to incorporate the Convention as an integral part of Community Law.

Keywords: Access to information. Right to participate. Aarhus Convention. European Union.

\section{Introdução}

O direito à participação representa a concreção do princípio democrático, maxime por implicar no acesso do indivíduo aos processos decisórios relativos à vida em sociedade. Trata-se, por conseguinte, de um direito de quarta geração, na medida em que os direitos à informação e à participação representam pontos essenciais para a formação de uma sociedade aberta e globalizada (BONAVIDES, 2007).

Doutora em Direito Público/Direito Comunitário pela Universidad Alcalá de Henares - Madrid. Assessora Jurídica do Setor de Assessoria Técnica Secretaria do MERCOSUL - Montevidéu (período: 2008-2009). Professora da Faculdade de Direito da Universidade Federal de Minas Gerais. Professora da Universidade de Itaúna-MG. Itaúna - MG - Brasil. E-mail: jmatadiz@yahoo.com.br.

Bacharel em Direito pela Faculdade de Direito da UFMG. Advogada. Pesquisadora e membro do Grupo de Pesquisa Estado e Política Internacional. Itaúna - MG- Brasil. E-mail: anaclaragd@uol.com.br. 
Em relação à participação ambiental de modo específico, pode-se asseverar ser esse direito um corolário do exercício da cidadania e da inclusão dos indivíduos acerca de temas relacionados ao meio ambiente - tais como os impactos (já ocasionados ou futuros) decorrentes da implementação de empreendimentos, a qualidade dos recursos naturais e os meios de preservação ambiental, entre outros -, além de reafirmá-lo como parte intrínseca da dignidade humana.

No âmbito internacional, diversos instrumentos normativos foram criados com previsões genéricas sobre o acesso à informação, mas, em 1998, foi firmada a Convenção de Aarhus, que tem como objetos específicos o acesso à informação, a participação popular e o acesso à justiça em matéria de meio ambiente.

A importância da referida Convenção é a de conferir uma maior concreção ao princípio da transparência, dentro de um quadro de global governance, por meio da iniciativa de se viabilizar que qualquer cidadão, ou pessoa jurídica, possa obter informações ambientais, inclusive referentes a outros países, em uma verdadeira tentativa de regionalizar e promover o intercâmbio dos dados.

Tal direito fundamental resguardado pela Convenção de Aarhus, é de se mencionar, já foi objeto de discussão na Corte de Justiça Europeia, razão pela qual ora se toma para estudo desse tema o paradigma referente ao processo de autos C-204/09 - Flachglas Torgau GmBH versus Alemanha, segundo o qual uma recusa injustificada para prestar informações ambientais solicitadas pelo autor por si só acabou levando-o a ajuizar uma ação baseada justamente em sua previsão normativa.

O Brasil não é país signatário da Convenção de Aarhus, visto que se trata de instrumento normativo elaborado e negociado no âmbito da Comissão Econômica das Nações Unidas para a Europa (CEE/ ONU), sendo justamente por isso que não é muito estudada ou divulgada no meio jurídico nacional, apesar de ser considerada pela Organização das Nações Unidas (ONU) o instrumento mais avançado para a democracia ambiental.

A pesquisa sobre o tema revela-se, destarte, de suma importância, principalmente porque, embora o Brasil não seja parte da Convenção de Aarhus, o princípio da informação ambiental deve ser resguardado em sua plenitude e, desse modo, o Estado brasileiro deve se propor a efetivar sua aplicação para toda a sociedade.

Nesse sentido, o presente trabalho visa constatar a importância do Direito Internacional para a construção e consolidação do Direito Ambiental interno, com foco na Convenção de Aarhus, sua implementação e utilização como parâmetro para as normas brasileiras. Agora, no marco de uma política protetiva do meio ambiente, deve-se analisar ainda como serão estipuladas as medidas que deverão ser observadas pelos Estados, e até mesmo por suas próprias instituições, no momento da adoção de planos, programas, projetos, atos e ações que venham a fixar níveis de proteção ambiental que se mostrem efetivamente sustentáveis.

A consideração da proteção ambiental resultou, nesse aspecto, na adoção do princípio da participação, quando se determinou que toda ação, medida, norma ou programa de natureza pública ou privada - relacionados com a temática ambiental - deveria ser acessível, de modo amplo, a toda e qualquer pessoa física ou jurídica, de forma a permitir uma real inclusão dos indivíduos no processo de tomada de decisão.

O enfoque do presente trabalho é analisar o desenvolvimento normativo e jurisprudencial presente na aplicação do princípio da participação a partir da incorporação da Convenção de Aarhus como instrumento integrante do Direito Comunitário a ser observado pelos Estados partícipes desse processo de integração.

A metodologia de trabalho centra-se nos principais aspectos estabelecidos para uma pesquisa interdisciplinar que envolve temas de Direito Ambiental e seu tratamento pelo Direito Internacional e Comunitário, devido especialmente ao caráter específico e singular que deve estar presente em toda análise de um sistema jurídico próprio e aplicado a um determinado tipo de relação interestatal, como é o caso da União Europeia (UE). 
No mesmo diapasão, devem-se utilizar métodos que permitam analisar a evolução da construção do direito ambiental e sua aplicação pelos Estados-membros. Os métodos histórico e indutivo permitirão estabelecer as premissas conceituais e práticas aplicadas ao tema d no marco do processo de criação das políticas setoriais escolhidas, no desenvolvimento do presente trabalho, por possuírem maior interrelação com o meio ambiente.

No que tange à vertente teórico-metodológica, planeja-se seguir uma linha crítico-metodológica, que, nas palavras de Gustin e Dias (2002, p. 41), "supõe uma teoria crítica da realidade e sustenta duas teses de grande valor para o repensar da Ciência do Direito e de seus fundamentos e objeto: a primeira defende que o pensamento jurídico é tópico e não dedutivo, é problemático e não sistemático."

\section{A informação como pressuposto básico para o exercício do direito de participação}

A informação é um registro de acontecimentos, objetos, ideias ou percepções sobre algo que existe ou que virá a existir. É um meio de transmissão de conhecimento por intermédio de formas verbais ou nãoverbais, o qual será utilizado pelo destinatário para formulação de suas próprias concepções e, por isso, a informação está intimamente ligada à liberdade de expressão e de opinião, na medida em que "sem a liberdade, aquele que produz a informação ou quem a transmite não poderá assegurar a idoneidade e a veracidade dessa informação." (MACHADO, 2006, p. 31).

Sem a possibilidade de se informar e ter dados autênticos e que correspondam à realidade, o indivíduo não pode interpretar e fazer uso dos dados obtidos em movimentos de participação perante a sociedade, pois não serão confiáveis.

O acesso à informação, assim, possui dois objetivos: o desenvolvimento pessoal do indivíduo pela obtenção de conhecimento e a transparência do Estado, que deve possuir uma cultura de acesso livre às informações que sejam de interesse social (SCHLACKE; SCHRADER; BUNGE, 2009). Desse modo, a informação é essencial para assegurar a viabilidade da participação popular em uma sociedade democrática, na qual cada um poderá se expressar e se envolver na tomada de decisões a respeito de temas de interesse social.

No intuito de permitir a circulação de informações no sentido governo-cidadãos, surgiu o direito ao acesso à informação, considerado fundamental, uma vez que compreende uma parte significativa para o desenvolvimento da pessoa em sua totalidade, inerente a todos os seres humanos. Há que se ter presente que quatro seriam as características necessárias para se configurar uma informação como adequada ao intuito de respaldar o direito ao seu acesso: a veracidade, a amplitude, a tempestividade e a acessibilidade (SAMPAIO; WOLD; NARDY, 2003).

Segundo Pastor e Fuentes i Gasó (2008), o direito ao acesso à informação possui três funções básicas e complementares: a primeira função corresponde ao âmbito individual do titular do referido direito, que busca satisfazer seu interesse sobre uma informação independentemente de suas razões. A segunda função possui uma dimensão objetiva, na medida em que influencia o modo de funcionamento da administração pública e implica a melhoria da transparência e da eficácia. Por fim, o direito ao acesso à informação permite a aquisição de conhecimento pelo indivíduo, que poderá ser utilizado na defesa de seus direitos ou interesses.

Já Amado (2010) analisa duas dimensões do acesso à informação: primeiramente, a objetiva, que corresponde ao controle da transparência do Poder Público, com a justificativa para suas decisões e

Parte das ideias contidas neste tópico se verificam anteriormente desenvolvidas em Mata Diz e Discacciati (2015), razão pela qual a este texto ora se refere expressamente e também se remete o leitor para uma leitura complementar sobre o tema do acesso à informação ambiental e participação da sociedade. 
processos administrativos; e a subjetiva, na medida em que o cidadão compreende o fundamento e o limite de seus direitos perante as autoridades públicas.

Diante da importância desse direito, ele foi sendo gradualmente incluído na legislação nacional de diversos Estados que garantiam o acesso à informação de uma forma geral. $\mathrm{O}$ acesso à informação está assegurado na Declaração Universal dos Direitos Humanos, em seu art. 19, no Pacto Internacional dos Direitos Civis e Políticos, que incluiu a possibilidade de restrição do acesso quando devidamente fundamentado e expressamente incluído em lei (art. 19, incisos 2 e 3), e na Convenção Americana de Direitos Humanos, no seu art. 13, configurando-se, desse modo, em verdadeiro direito fundamental.

$\mathrm{Na}$ Convenção Europeia para a Proteção dos Direitos do Homem e das Liberdades Fundamentais, o direito de acesso à informação está incluído no artigo referente ao direito à liberdade de pensamento, na medida em que o recebimento e a transferência de dados deve ser isenta de influências estatais conforme disposto no art. 10.

Nos Estados Unidos, o Freedom of Information Act é datado de 1966, e foi reformulado em 1974 para atribuir maior eficácia no acesso às informações em posse do Poder Executivo, as quais poderão ser requisitadas por qualquer pessoa, detentora ou não de cidadania norte-americana. A disponibilização de informações está intimamente ligada à transparência de um governo e, em um segundo momento, à possibilidade de integração do indivíduo na política e gestão locais.

No âmbito da União Europeia, a informação ambiental se aplicava somente ao intercâmbio de informações entre os Estados em normas específicas, principalmente de prevenção de acidentes e manutenção dos parâmetros de qualidade ambiental. Como exemplo, tem-se a Diretiva 82/501/CEE, relativa aos riscos de acidentes graves de atividades industriais determinadas, e a Diretiva 96/62/CE (revogada pela Diretiva 2008/50/CE), sobre a avaliação e gestão da qualidade do ar.

Mais avançadas no sentido de buscar a participação popular no acesso à informação, podem-se mencionar a Diretiva 85/337/CEE, referente à avaliação dos efeitos de determinados projetos públicos e privados sobre o meio ambiente, que, além de ter sido muito relevante naquele momento para a formação de bancos de dados ambientais e para o monitoramento do meio ambiente impactado pelas atividades humanas, trouxe a previsão de disponibilização das informações e realização de consultas com o público interessado/afetado pelos empreendimentos a então se concretizarem, bem como a Diretiva 90/313/ $\mathrm{CE}$, relativa à liberdade de acesso à informação em matéria ambiental, que já refletia a preocupação do legislador comunitário de promover a transparência dos dados sobre o meio ambiente em posse das autoridades e de permitir a participação da população por meio do acesso às informações desejadas.

A fim de se estabelecer uma política de ação em comum para todos os Estados-membros, vários instrumentos sobre a temática ambiental foram elaborados pela Comissão Europeia. Os programas de ação, publicados desde 1972 e que já se encontram na $7^{\text {a }}$ versão, revelam que

\footnotetext{
[...] a inclusão da proteção do meio ambiente no rol de políticas que são decididas pelas instituições comunitárias demandou a criação de uma ordem jurídica voltada para a criação de medidas e ações destinadas a garantir que a proteção do meio ambiente possa ocupar um espaço central na agenda de discussões do processo comunitário. (MATA DIZ; GOULART, 2013, p. 38).
}

O $6^{\circ}$ Programa foi lançado em 2001 e continha previsão de informações aos consumidores no sentido de incentivar um estilo de vida mais saudável, de forma que tais informações deveriam estar incluídas nos produtos. Tal Programa, vale ressaltar, possui menção expressa à Convenção de Aarhus, malgrado sua aplicação se desse de forma tímida: "De um modo mais geral, a ratificação e a aplicação da Convenção de Aarhus sobre o 'Acesso à informação e participação do público em questões ambientais' também contribuirá para uma melhor aplicação da legislação comunitária pelos Estados-Membros." (COMISSÃO EUROPEIA, 2007). O ponto de confluência, assim, era a incorporação da preocupação ambiental nas políticas econômicas europeias, concretizando-se o princípio da integração ante sua transversalidade (MATA DIZ; GOULART, 2013). 
Percebe-se que a informação ainda não era utilizada como instrumento de participação pelo cidadão na tomada de decisões ambientais. Entretanto, o acesso à informação ambiental pelos cidadãos foi incluído no $7^{\circ}$ Programa, hoje em vigor, sendo um dos seus objetivos a melhoria da qualidade e da divulgação das informações para aperfeiçoamento da base de conhecimentos

O PAA reconhece a importância de um maior acesso público à informação para melhorar o entendimento público sobre as questões ambientais e ajudar as pessoas a garantir melhorias ao seu próprio ambiente. Reconhece a necessidade de um sistema melhorado de inspeções e supervisão, assim como um melhor acesso à justiça no que toca às questões ambientais (COMISSÃO EUROPEIA, 2007).

Em 1992, por ocasião da Conferência das Nações Unidas sobre o Meio Ambiente e Desenvolvimento, houve a consolidação do acesso à informação ambiental consubstanciado em um princípio elencado na Declaração do Rio:

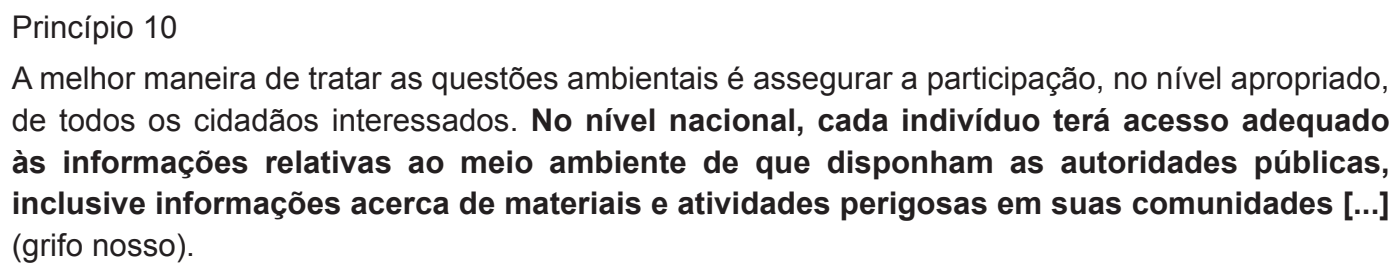
de todos os cidadãos interessados. No nível nacional, cada indivíduo terá acesso adequado às informações relativas ao meio ambiente de que disponham as autoridades públicas, inclusive informações acerca de materiais e atividades perigosas em suas comunidades [...] (grifo nosso)

Buscava-se, desse modo, assegurar a todos, de forma democrática e igualitária, o acesso a essas informações. Com esse novo entendimento sobre a importância do acesso do público às informações ambientais, entendeu-se que a participação popular somente é viável quando o cidadão detiver um mínimo de conhecimento a respeito, porquanto fundamental para uma atuação eficaz, eficiente e efetiva. Nas palavras de Pastor e Fuentes i Gasó (2008), o acesso à informação ambiental serve de fundamento para o exercício consciente de outros direitos, possuindo, destarte, um caráter instrumental.

Caso a informação seja insuficiente, inacessível ou incompreensível por ausência de conhecimento técnico ou linguajar científico, o indivíduo perde sua capacidade de participar coerentemente, visto que não terá dados para embasar sua decisão ou questionamento (SOLÉ; PENTINAT, 2008).

Em uma relação desigual entre indivíduos, empresários, governo e demais interessados, a busca pelo direito ao meio ambiente equilibrado necessita de meios para aprimorar a participação da sociedade, o que foi devidamente observado na Conferência do Rio. Após frustradas tentativas de implementação de um instrumento em âmbito internacional que assegurasse essa pretensão, os esforços empreendidos pela CEE/ONU culminaram em um texto de Direito Internacional, a já comentada Convenção de Aarhus, que será melhor estudada a seguir.

\section{A Convenção de Aarhus e a regulação da participação ambiental pelo direito internacional}

O direito à informação ambiental, à participação e ao acesso à justiça em matéria ambiental já era resguardado em declarações, tais como a Declaração do Rio, e resoluções de organizações internacionais. Tais instrumentos, todavia, são considerados soft law, isto é, possuem a característica de não serem vinculantes, sendo vistos pelos países como recomendações a serem seguidas.

Segundo Nasser (2006), as declarações são geralmente resultado de conferências internacionais, ao final das quais um documento com objetivos e compromissos políticos e programáticos são estipulados, enquanto as resoluções, por sua vez, são elaboradas por deliberações de organizações internacionais. O compromisso internacional firmado entre os países nas declarações e a força jurídica das resoluções não são suficientes para atribuir-lhes a obrigatoriedade de observância: faltava ainda um meio com maior força no âmbito internacional para garantir, de fato, as implementações das necessárias mudanças pelos Estados. 
Desse modo, após dois anos de negociações entre os diversos países da região abrangida pela CEE/ONU (contando ainda com a intensa participação de organizações não governamentais), a Convenção sobre Acesso à Informação, Participação do Público no Processo de Tomada de Decisão e Acesso à Justiça em Matéria de Ambiente, comumente chamada de Convenção de Aarhus, foi elaborada e adotada por 35 (trinta e cinco) países por ocasião da $4^{\text {a }}$ Conferência Ministerial de Meio Ambiente para a Europa, organizada pela CEE/ONU e realizada em 25 de junho de 1998, na cidade de Aarhus, Dinamarca. Atualmente, 46 (quarenta e seis) países assinaram a convenção, além da União Europeia como organização supranacional.

Trata-se de um instrumento internacional que, ao contrário da maioria dos tratados firmados, não possui em seu conteúdo obrigações entre as partes, mas, sim, deveres para com a sociedade, público-alvo dos direitos ali garantidos. Há uma junção entre direitos humanos e ambientais, objetivando o envolvimento da sociedade nas políticas públicas a serem implementadas pelos governos frente aos desafios modernos de proteção do meio ambiente. A especialidade desse instrumento é enfatizada pelos organizadores do Guia de Implementação da Convenção de Aarhus, pois a Convenção não é somente um acordo sobre meio ambiente; é também um acordo sobre responsabilidade governamental, transparência e acessibilidade. $\square$ (ONU, 2012).

O preâmbulo reforça a relação direta entre direitos ambientais e direitos humanos, na medida em que reconhece o direito de todos a um ambiente saudável e adequado para seu bem-estar. Ele também reconhece que a proteção ambiental depende das políticas governamentais, mas estipula que, para isso, os anseios e manifestações da população devem ser observados.

As regras gerais estão dispostas nos artigos $1^{\circ}$ a $3^{\circ}$. No artigo $1^{\circ}$, está o objetivo da Convenção, que é o de garantir a proteção do direito dos indivíduos a viver em um ambiente saudável, que será alcançado por meio dos outros direitos ali garantidos. Há menção à necessidade de promover a preservação ambiental também para as futuras gerações, reforçando, desse modo, o princípio da responsabilidade intergeracional, consoante as declarações sobre a temática ambiental que fundamentaram a Convenção.

O $2^{\circ}$ artigo contém a definição dos principais conceitos necessários para a compreensão e interpretação das normas estabelecidas na Convenção, tais como os significados de "informação ambiental" e "autoridade pública". A definição de "público" é bastante abrangente, com um tratamento democrático que inclui pessoas físicas ou jurídicas, associações, organizações e grupos; enquanto que a expressão "público interessado" corresponde a todos os eventuais interessados nas informações ambientais, com especial vínculo a um procedimento específico de decisão em matéria ambiental. Ressalta-se a vedação à discriminação por nacionalidade, domicílio ou cidadania, de modo que o acesso aos direitos assegurados na Convenção de Aarhus deve ser facilitado a todos os que assim requererem. Já o artigo $3^{\circ}$ estabelece disposições gerais, relacionadas principalmente às obrigações dos Estados-partes para garantir a exequibilidade da Convenção, por via da implementação de medidas que, v. g., conciliem o direito interno às disposições da Convenção.

Para Schlacke, Schrader e Bunge (2009, p. 5), "a Convenção tem um conceito que é relativamente novo, pelo menos em direito ambiental internacional: a promoção da proteção do ambiente através de direitos processuais subjetivos, que devem ser usufruídos pelos cidadãos e pelas associações ambientais". Esses direitos assegurados correspondem aos denominados pilares da Convenção, quais sejam: o direito de acesso à informação ambiental (arts. $4^{\circ}$ e $5^{\circ}$ ), o direito de participação em procedimentos de tomada de decisões (art. $6^{\circ}$ ) e o direito de acesso à justiça em matéria ambiental (arts. $7^{\circ}$ e $8^{\circ}$ ).

A Convenção de Aarhus adota o conceito de democracia participativa, na qual a informação, a participação e o acesso efetivo à justiça são premissas fundamentais para a atuação efetiva do cidadão na proteção do meio ambiente. Esses direitos também implicam a possibilidade de se exigir a responsabilidade das autoridades públicas no que diz respeito à política ambiental. Uma vez voltada para o público, ela busca sensibilizar a população para os problemas do meio ambiente e promover a educação ambiental, na medida em que inclui o cidadão como elemento necessário para a preservação da natureza. 
O primeiro pilar é o direito ao acesso à informação, assegurado de duas formas distintas. Pela via da difusão passiva, há o direito de buscar e obter uma informação que esteja em poder da autoridade pública, que é, portanto, provocada a se manifestar por meio de solicitações devidamente endereçadas ao Poder Público, sem a necessidade de justificativa. Já pela difusão ativa da informação, o cidadão ou pessoa jurídica interessada possui o direito de receber as informações ambientalmente relevantes pelo governo, por meio da publicação, em caráter geral e para toda a sociedade, de dados e relatórios oficiais, sem a necessidade de solicitação prévia (PASTOR; FUENTES i GASÓ, 2008).

Essas duas formas estão minudentemente descritas nos dois artigos da Convenção de Aarhus sobre o direito à informação ambiental. $\mathrm{O}$ art. $4^{\circ}$ prevê o direito de uma pessoa física ou jurídica de formular pedido de acesso às informações em poder do Estado ou de agentes privados que atuem em funções estatais, sem a necessidade de motivação ou interesse direto. Trata-se, portanto, de uma iniciativa do particular que se manifesta mediante provocação direcionada ao Poder Público para a obtenção das informações desejadas.

A resposta da autoridade pública é obrigatória, e o pedido somente poderá ser negado (com o fim de se evitar a confidencialidade de procedimentos), mediante a devida justificativa, nos casos previstos na Convenção, tais como: garantir a segurança pública, assegurar a proteção dos segredos industriais ou se a autoridade não detiver a informação desejada, situação na qual deverá indicar qual a autoridade competente. Trata-se, desse modo, de um ato administrativo vinculado, desprovido de qualquer discricionariedade para a prestação das informações solicitadas. O prazo de resposta é de um mês, prorrogável por igual período somente com justificativa e comunicação ao interessado.

$\mathrm{O}$ art. $5^{\circ}$ traz a previsão de outra modalidade de acesso à informação, cujo polo ativo é o próprio Estado. É o dever de produzir e divulgar informações ambientais periodicamente para o público em geral. Desse modo, surge uma obrigação continuada para o Estado de elaboração de relatórios e avaliações da qualidade ambiental em seu território. Propõe-se, com essas medidas, um meio de manter a população consciente acerca da qualidade do meio ambiente e dos efeitos causados por atividades, como já fora proposto nos estudos de impacto ambiental, os quais devem ser de fácil acesso e compreensão do público.

Os estudos de impacto ambientais (EIA), com os respectivos relatórios de impactos ambientais (RIMA), representam a publicidade dos empreendimentos a serem realizados, tanto pelo Poder Público como por particulares. Eles contêm informações sobre o projeto, os possíveis impactos que poderão ser causados, bem como as medidas mitigadoras a serem perpetradas. A relação do EIA/RIMA com as informações ambientais que devem ser disponibilizadas ao público provém da imperiosidade de acesso dos cidadãos, afetados pelo empreendimento ou não, aos dados contidos nos relatórios.

Uma vez de conhecimento da sociedade, ela poderá utilizar tais informações para demandar mudanças ou participar ativamente da fiscalização do devido cumprimento das medidas impostas para minimizar os impactos a serem causados. ${ }^{2}$ Além disso, há a obrigação de informar as pessoas potencialmente atingidas por ameaças ambientais causadas pela natureza ou pela ação humana.

As informações ambientais a serem prestadas à sociedade, seja na modalidade ativa, seja na passiva, correspondem aos dados relacionados a três grupos, conforme disposto na Convenção em seu art. 2.3: i) as informações referentes ao estado do meio ambiente; ii) aquelas que fazem referência a fatores que possam causar modificações neste ambiente; e, por fim, iii) os dados relacionados ao estado de saúde humana. Logo, percebe-se que o indivíduo poderá se informar acerca do que se passa em sua localidade ou acompanhar as mudanças que poderão ocorrer, na medida em que terá acesso ao que se

Também no âmbito da CEE/ONU pode-se mencionar a Convenção de Espoo (Convenção Relativa à Avaliação dos Impactos Ambientais num Contexto Transfronteiras), de 1991, que não obstante trate da obrigatoriedade de realização de estudos de impacto ambiental no âmbito de projetos transfronteiriços, já estabeleceu os moldes para tal exigência pelos países signatários também internamente. 
refere a como estava o meio ambiente, o que o terá influenciado e quais as consequências para o seu bem-estar.

Na posse de tais informações, viabiliza-se o próximo direito assegurado pela Convenção, que já havia sido mencionado na Declaração do Rio. O direito de participação é o segundo pilar da Convenção de Aarhus e propõe o envolvimento democrático da sociedade nas questões ambientais. Está regulado pelo artigo $6^{\circ}$, o qual contém a previsão de organização de consultas públicas, previamente informadas aos interessados, nas quais ocorrerá a tomada de decisões sobre a temática ambiental, em conjunto com os órgãos públicos. Para a atuação efetiva dos cidadãos, a Convenção de Aarhus novamente dispõe sobre a necessidade de prover informações tempestivamente e de forma adequada, o que representa a íntima ligação entre os direitos resguardados.

Desse modo, a Convenção foi organizada estruturalmente de acordo com o encadeamento que cada direito possui em relação ao próximo. Há uma interrelação entre os direitos resguardados pela Convenção, na medida em que o acesso à informação é inerente para a adequada participação, e ambos os direitos têm sua efetividade e exercício assegurados pela possibilidade de garantias judiciais (LIZARRAGA; ESPINOSA, 2007). A efetividade da participação, desde indivíduos até organizações não governamentais engajadas com o tema na esfera administrativa, depende da disponibilidade de informações precisas e pertinentes para a tomada de decisão relacionada ao meio ambiente. Para tanto, há a necessidade de implementação de dois princípios junto às políticas públicas: o princípio de abertura, que inclui a facilitação da linguagem utilizada nos relatórios e dados sobre o meio ambiente e uma maior acessibilidade por parte do cidadão; e o denominado de participação, segundo o qual a atuação do público deve ser promovida e incentivada em todas as fases do processo de tomada de decisão.

As formas de participação devem abranger todas as camadas da sociedade, de preferência aquelas pessoas cujo meio ambiente será afetado em sua qualidade ou disponibilidade, o que corresponde ao verdadeiro objetivo da democracia ambiental. Desse modo, busca-se uma igualdade na participação, não sendo possível restringir ou discriminar um determinado grupo. A justiça ambiental almejada pelo instrumento internacional é, segundo definição da Agência de Proteção Ambiental dos Estados Unidos da América (EPA), "o tratamento justo e o envolvimento significativo de todas as pessoas, independentemente de raça, cor, cidadania ou renda no que tange ao desenvolvimento, implementação e aplicação das leis, regulações e políticas ambientais."3

O envolvimento significativo abrange a possibilidade de participação nas decisões sobre atividades que possam afetar o meio ambiente local e/ou sua saúde, a contribuição do público que pode influenciar na decisão da agência reguladora, a possibilidade das suas preocupações serem consideradas no processo de tomada de decisão, e a busca e promoção, pelas autoridades públicas, da participação das pessoas potencialmente afetadas.

Essas formas de participação correspondem aos artigos $7^{\circ}$ e $8^{\circ}$ da Convenção, os quais determinam a inclusão da sociedade, tanto nos procedimentos administrativos - tais como, elaboração de políticas e planos em matéria ambiental -, como no processo legislativo, na medida em que as pessoas deverão ser partícipes diretas na preparação de instrumentos normativos. A Convenção não determina, ao contrário do direito ao acesso à informação, os procedimentos e exigências para o exercício do direito à participação. Entende-se, segundo o Guia de Implementação da Convenção de Aarhus (2014, p. 119), que

Não há fórmula definida para participação do público, mas, no mínimo exige-se uma notificação eficaz, as informações adequadas, procedimentos próprios e tomar em consideração o resultado

Livre tradução do seguinte trecho: "Environmental Justice is the fair treatment and meaningful involvement of all people regardless of race, color, national origin, or income with respect to the development, implementation, and enforcement of environmental laws, regulations, and policies." (AGÊNCIA DE PROTEÇÃO AMBIENTAL DOS ESTADOS UNIDOS DAAMÉRICA - EPA). 
da participação popular. O nível de envolvimento do público num processo específico depende de distintos fatores, incluindo o resultado esperado, o objetivo, quem e quantos serão afetados, se o resultado envolve questões nacionais, da região ou locais, e assim por diante. Além disso, pessoas diferentes podem ter diferentes status no âmbito da participação em um assunto em especial. ${ }^{4}$

Destarte, cabe aos Estados-partes da Convenção assegurar a participação do público por meio da comunicação tempestiva e disposição das informações necessárias à efetiva contribuição, como também das propostas legislativas das causas para elaboração de determinado plano, etc. A sua importância, por conseguinte, é bem resumida por Duvic-Paoli (2012, p. 83), ao estabelecer que, "sendo um direito ambiental, o princípio da participação do público está na intersecção entre direito ambiental internacional e direitos humanos." Quando confrontadas a reconhecer esse direito, diversas Cortes o incluíram nas previsões já estabelecidas, como o direito à privacidade e vida familiar, o direito à vida e o direito ao desenvolvimento. ${ }^{5}$

Como terceiro pilar, a Convenção garante o direito ao acesso à justiça em matéria ambiental em casos de violação dos dispositivos contidos na Convenção de Aarhus e nas leis nacionais de temática ambiental. Com a facilitação do acesso por meio da mudança e/ou implementação de regras nos Estadospartes da Convenção, o público deverá ter a possibilidade de questionar os atos das autoridades públicas, sejam de ação, seja de omissão, podendo ser referentes aos dois primeiros pilares ou a outros direitos, ou seja, direitos fundamentais inerentes a todos da população.

Assim, decisões administrativas poderão se objeto de litígio judicial, quando se entender que o Poder Público descumpriu os deveres colacionados na Convenção ou legislação nacional. Também às organizações da sociedade civil é assegurado o direito ao acesso à justiça, na medida em que representam uma parcela do público e, portanto, estão legitimadas para impugnar decisões com conteúdo ambiental, adotadas pelas autoridades públicas (LIZARRAGA; ESPINOSA, 2007).

Tal previsão remete ao direito ao processo equitativo (fair trial), consoante o art. $6^{\circ}$ da Convenção Europeia de Direitos do Homem, ${ }^{6} \mathrm{com}$ o qual pretende-se a apreciação pelo Judiciário de todas as alegadas violações de direitos, inclusive ambientais, fundadas em Aarhus, bem como remete também ao princípio $n^{\circ} 10$ da Declaração do Rio de 1992,, precursora no estabelecimento de princípios que assegurariam posteriormente direitos aos indivíduos.

O direito ao acesso à justiça está previsto no art. $9^{\circ}$ da Convenção de Aarhus, subdividido em cinco parágrafos, sendo que os três primeiros correspondem aos motivos que ensejam a prerrogativa de acionar a Justiça e denotam a intrínseca relação com os outros direitos assegurados e já mencionados. O primeiro caso é o pedido de acesso à informações requeridas conforme o art. $4^{\circ}$ (modalidade passiva), mas para o qual houve negativa injustificada ou indevida. Discute-se a conformidade do ato administrativo, ou a sua inexistência, quando for o caso de omissão do Poder Público.

O segundo parágrafo dispõe sobre a possibilidade de ajuizamento nas situações elencadas no artigo $6^{\circ}$. Segundo Lizarraga e Espinosa (2007), são três as hipóteses de necessária tutela judicial em virtude

4 Livre tradução do trecho "There is no set formula for public participation, but at a minimum it requires effective notice, adequate information, proper procedures and appropriately taking account of the outcome of the public participation. The level of involvement of the public in a particular process depends on a number of factors, including the expected outcome, its scope, who and how many will be affected, whether the result settles matters on a national, region or local level, and so on. In addition, different persons may have different status in connection with participation on a particular matter." Disponível em: <http://www.unece.org/fileadmin/DAM/env/pp/Publications/Aarhus_Implementation_Guide_interactive_eng.pdf> Acesso em: 02 fev. 2015.

5 A autora cita decisões da Corte Europeia de Direitos Humanos (Guerra e outros v. Italia, $n^{\circ} 14967 / 89$ e Önerryildiz v. Turquia, $n^{\circ}$ 48939/99) e da Comissão Africana de Direitos Humanos e dos Povos (Centre for Minority Rights Development, Communication n¹55/96).

6 "Art. $6^{\circ}$. Qualquer pessoa tem direito a que a sua causa seja examinada, equitativa e publicamente, num prazo razoável por um tribunal independente e imparcial, estabelecido pela lei, o qual decidirá, quer sobre a determinação dos seus direitos e obrigações de carácter civil, quer sobre o fundamento de qualquer acusação em matéria penal dirigida contra ela [...]". Disponível em: <http://www.gddc.pt/direitos-humanos/textosinternacionais-dh/tidhregionais/conv-tratados-04-11-950-ets-5.html> Acesso em: 05 fev 2015.

7 "Princípio $10-[\ldots]$ Será proporcionado o acesso efetivo a mecanismos judiciais e administrativos, inclusive no que se refere à compensação e reparação de danos". 
de descumprimento do direito à participação: quando uma informação for difundida de modo incompleto, restringindo, assim, a possibilidade do exercício efetivo e consciente da participação social; quando existirem obstáculos que inviabilizem a participação de pessoas ou entidades na tomada de decisões referentes ao meio ambiente; ou quando requisitos e características sejam exigidos como prova de legitimação para participar nos procedimentos. Desse modo, pode-se pleitear em juízo a anulação das decisões e a retomada do processo decisório com a devida participação.

Pedidos de revisão de atos ou omissões de qualquer natureza que impliquem descumprimento da legislação ambiental, e que tenham sido praticados por particulares no exercício de funções estatais ou pelas autoridades públicas, de acordo com o parágrafo $3^{\circ}$, também podem ser objeto de demanda judicial. Os parágrafos $4^{\circ}$ e $5^{\circ}$ contêm previsões para os signatários da Convenção na implementação de um processo célere, não dispendioso e equitativo, além de promover a informação referente ao processo, administrativo ou judicial, e prover assistência judiciária aos que não podem arcar com os custos, de modo a evitar a discriminação de qualquer natureza, em consonância com o art. $4^{\circ}$.

Busca-se, portanto, o fortalecimento da sociedade civil, principalmente das organizações ambientalistas, mediante o envolvimento do público na esfera administrativa. Entretanto, segundo o Guia de Implementação da Convenção de Aarhus, publicado pela CEE/ONU, entende-se que as disposições gerais do texto são "um chão, e não um teto" (LIZARRAGA; ESPINOSA, 2007, p. 43), ou seja, correspondem ao mínimo necessário comum a todas as partes da Convenção para a eficácia das medidas apresentadas.

Não obstante seja dever do Poder Público viabilizar essa necessária inclusão, ela deverá ser exercida pela população de modo geral, tendo em vista o princípio da responsabilidade comum de todos para a proteção do meio ambiente. Desse modo, reitera-se a possibilidade de que os Estados, de acordo com suas peculiaridades econômicas, sociais e culturais, ampliem o acesso à informação, à participação popular e à justiça em matéria ambiental.

\subsection{Incorporação ao direito europeu como mecanismo de fortalecimento do desenvolvimento sustentável}

No âmbito europeu, a proteção do meio ambiente ainda era tutelada pelos tribunais supranacionais de forma reflexa. Ocorre que a Convenção Europeia de Direitos Humanos, por exemplo, não previa o direito a um meio ambiente saudável. Assim, os casos que chegavam à Corte de Estrasburgo utilizavam o artigo $2^{\circ}$ (direito à vida), 6.1 (direito a um processo equitativo, segundo o qual toda demanda possui o direito de ser examinada) e $8^{\circ}$ (direito ao respeito pela vida privada e familiar) da Convenção como fundamento para pleitear uma ação ou abstenção do Poder Público, ou de particulares, e que garantisse a melhoria das condições ambientais. ${ }^{8}$ Em face de tais pleitos, houve, nas palavras de Lizarraga e Espinosa (2007), uma "ecologização ou greening" dos direitos humanos abrangidos pela Corte Europeia de Direitos Humanos, causando notável avanço da legislação europeia acerca do tema de meio ambiente. O que surgia, portanto, era uma aproximação entre direitos humanos e direitos ambientais, dentre os quais estão incluídos o exercício desses direitos, tais como as garantias resguardadas pela Convenção de Aarhus. ${ }^{9}$

Na esteira do movimento em prol da melhor abordagem para a preservação ambiental com o aumento da inclusão da sociedade, a Convenção de Aarhus, como anteriormente mencionado, fora elaborada no

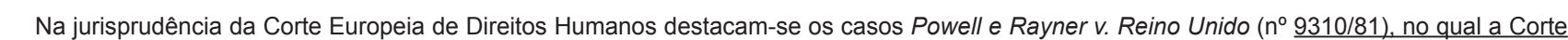
entendeu que o barulho causado pelo aeroporto de Heathrow impedia o gozo pleno do direito à vida privada, e López Ostra $v$. Espanha ( ${ }^{\circ}$ $\underline{16798 / 90}$ ), quando foi julgado que o barulho e os odores provenientes de uma usina de tratamento de resíduos também limitavam os direitos dos cidadãos. Em julgamento mais recente, a Corte entendeu no caso Giacomelli v. Itália que, apesar de maneira não explícita, o artigo $8^{\circ}$ da Convenção Europeia de Direitos Humanos abrangeria a necessidade de informação e a possibilidade de participação na decisão sobre políticas públicas e econômicas, bem como em projetos que impactem o meio ambiente ao seu redor e que poderiam trazer prejuízos ao direito garantido.

9 A relação entre o efetivo exercício dos direitos humanos com as prerrogativas presentes na Convenção de Aarhus está explícita em seu oitavo considerando: "Considerando que para defender este direito [a viver num ambiente adequado à sua saúde e bem-estar] e cumprir este dever [de proteger e melhorar o ambiente em benefício das gerações actuais e vindouras], os cidadãos devem ter acesso à informação, ter direito a participar no processo de tomada de decisão e ter acesso à justiça em matéria de ambiente e reconhecendo que a este respeito os cidadãos possam necessitar de ajuda a fim de poder exercer os seus direitos".
} 
âmbito da CEE/ONU, incluindo, portanto, também a UE, além dos Estados que a integram, como possível parte, pois a UE é considerada sujeito de direito internacional em decorrência do reconhecimento de sua personalidade jurídica. Como embasamento legal para as competências externas da UE, consta no art. 216 do Tratado sobre o Funcionamento da União Europeia (TFUE) ${ }^{11}$ a previsão das hipóteses em que é possível a assinatura de acordos internacionais pela UE.

A competência internacional entre UE e Estados-membros também é repartida em exclusiva e partilhada. Diferentemente de sistemas federais tradicionais, a lógica de repartição de competências em um sistema comunitário como a União Europeia denota uma atenção mais detida. Molina del Pozo e Mata Diz (2013) entendem que as competências são estabelecidas não territorialmente, mas segundo a matéria, de modo a assegurar uma função ou alcançar um fim almejado por todos os Estados-membros. Nas palavras dos autores,

[se] de ordem econômica e social, as competências se atribuem à Comunidade ou aos Estados membros de acordo, primeiro, com o mecanismo denominado de 'competências concorrentes' também chamadas concorrências interinadas - trasladada dos modelos federais e, segundo, em termos de competências exclusivas da Comunidade. Em virtude do caráter concorrente das competências que se distribuem entre ambos os níveis, os Estados membros conservam sua capacidade legislativa e executiva sobre aquelas matérias em que os Tratados preveem uma reserva de competência a favor da Comunidade enquanto esta não 'reclame' sua competência mediante seu exercício, ditando normas cujo efeito indireto é o de deslocar a competência nacional para o âmbito comunitário. (MOLINA DEL POZO; MATA DIZ, 2013, p. 38). ${ }^{12}$

Desse modo, quando for o caso de competência concorrente, os países, em nome próprio, podem também negociar e, ao final, assinar em conjunto com a UE o ato internacional. ${ }^{13}$ Ressalte-se que, em ambos os casos - competência exclusiva ou concorrente -, o acordo internacional valerá para a UE e também para os Estados-membros, conforme o parágrafo $2^{\circ}$ do art. $216 .{ }^{14}$

As competências concorrentes estão elencadas no art. $4^{\circ}$ do TFUE, que estabelece os domínios em que os Estados-membros podem legislar, sempre em consonância com o Direito Comunitário, bem como firmar acordos internacionais. A letra E do artigo mencionado traz o tema "ambiente", o que autoriza, destarte, a participação dos países em tratados internacionais que versem sobre tal matéria. O exercício das competências concorrentes deve seguir os princípios da subsidiariedade e da proporcionalidade ${ }^{15}$, e as obrigações devem ser repartidas na medida de possibilidade de execução, tanto pela UE como pelos Estados-membros, obtendo-se, portanto, uma atuação paralela e complementar para contemplar, no presente caso, os direitos assegurados pela Convenção de Aarhus (BONDÍA, 2008).

Por conseguinte, a Convenção de Aarhus pode ser assinada tanto pela UE como pelos países que a compõem e que são membros da CEE/ONU, o que ocorreu na elaboração do texto, em 25 de junho de

11 "Art. 216 - A União pode celebrar acordos com um ou mais países terceiros ou organizações internacionais quando os Tratados o prevejam ou quando a celebração de um acordo seja necessária para alcançar, no âmbito das políticas da União, um dos objectivos estabelecidos pelos Tratados ou quando tal celebração esteja prevista num acto juridicamente vinculativo da União ou seja susceptível de afectar normas comuns ou alterar o seu alcance".

12 Livre tradução: "[se] de orden económico y social, las competencias se atribuyen a la Comunidad o a los Estados miembros de acuerdo, primero, con el mecanismo denominado de 'competencias concurrentes'- también llamadas competencias interinadas -, acunado en los modelos federales $y$, segundo, en términos de competencias compartidas o exclusivas de la Comunidad. En virtud del carácter concurrente de las competencias que se distribuyen entre ambos niveles, los Estados miembros conservan su capacidad legislativa y ejecutiva sobre aquellas materias en que los Tratados realizan una reserva competencial a favor de la Comunidad en tanto que esta no 'reclame' su competencia mediante su ejercicio, dictando normas cuyo efecto indirecto es el de desplazar la competencia a nivel nacional a sede comunitaria".

13 Não obstante a redação do TFUE que inclui a temática ambiental como competência concorrente, é interessante ressaltar que o Tribunal de Justiça da União Europeia reconheceu a possibilidade de a União Europeia firmar acordos internacionais acerca de temas que não foram explicitamente atribuídos pelos tratados, caracterizando a existência das competências implícitas. Neste sentido, vide Molina del Pozo e Mata Diz (2013).

14 "Art. 216 [...] 2. Os acordos celebrados pela União vinculam as instituições da União e os Estados-Membros".

15 Os princípios da atribuição, subsidiariedade e proporcionalidade são de grande importância para a melhor compreensão da divisão de competências da União Europeia. Sobre o princípio da atribuição, entende-se que a União somente poderá atuar de acordo com os limites das competências que lhe foram atribuídas pelso Tratados, que as enumera de forma taxativa, sendo que aquelas não apontadas são de competência dos Estados-Membros. Já o princípio da subsidiariedade determina que, em relação a competências partilhadas, a União pode atuar no intuito apenas de auxiliar os Estados-Membros quando os objetivos estipulados não puderem ser alcançados individualmente. Por fim, o princípio da proporcionalidade prevê que o conteúdo e a forma dos atos realizados pela União Europeia devem se ater estritamente aos objetivos estipulados pelos Tratados. 
1998 ${ }^{16}$ A ratificação pela UE ocorreu em 17 de fevereiro de 2005, por meio da Decisão 2005/370/CE do Conselho. Desse modo, os governos nacionais e supranacional aderiram ao instrumento internacional, criando, para a execução dos objetivos nele expostos, uma estrutura com múltiplos níveis legislativos, em uma ideia de integração regional para a melhor transparência e eficiência no fornecimento de informações de cunho ambiental. Não somente os países estão vinculados aos deveres previstos na Convenção, como também deve a UE elaborar atos legislativos que regulamentem as disposições da Convenção de Aarhus.

Analisando o primeiro nível, supranacional, pode-se afirmar que a integração para o direito europeu dos ditames da Convenção foi devidamente realizada. Em cumprimento aos seus deveres instituídos pelo Direito Comunitário, no qual se estabelece a necessidade de incorporação do conteúdo de acordos internacionais firmados pela UE ao Direito interno, foi publicada a Diretiva 2003/4/CE, ${ }^{17}$ que trata do primeiro pilar da Convenção, bem como as partes do terceiro pilar relevantes para o acesso à informação, no âmbito da UE, conforme se depreende do $5^{\circ}$ considerando da Diretiva:

(5) Em 25 de Junho de 1998, a Comunidade Europeia assinou a Convenção da Comissão Económica para a Europa das Nações Unidas sobre o acesso à informação, a participação pública no processo de decisão e o acesso à justiça em matéria ambiental («Convenção de Aarhus»). As disposições da legislação comunitária devem ser compatíveis com essa convenção, tendo em vista a sua conclusão pela Comunidade Europeia (grifo nosso).

Logo, ainda que os Estados-membros não fossem parte da Convenção de Aarhus, no caso hipotético do meio ambiente ser tema de competência exclusiva da UE, estariam eles indiretamente vinculados, pois a Diretiva 2003/4/CE trouxe para o Direito europeu as obrigações da referida Convenção. Contudo, tendo em vista que os países integrantes da UE também são partes da Convenção de Aarhus, mesmo na ausência de instrumentos oriundos de Bruxelas, estariam eles obrigados a perseguir os objetivos estipulados no acordo internacional, ou seja, os Estado se obrigaram diretamente - quando da ratificação e incorporação da Convenção - e indiretamente - quando da adoção da referida Diretiva.

A importância da Diretiva 2003/4/CE decorre, então, da necessária coerência que deve existir entre as políticas nacionais e europeias em relação ao meio ambiente,$^{18}$ uma vez que os problemas ambientais não respeitam fronteiras políticas e a proteção deve ocorrer de forma conjunta (GUCKELBERGER, 2008). Para isso, a Diretiva já dispõe, em seu art. $1^{\circ}$, os objetivos a serem alcançados, quais sejam: 1) a implementação de formas de obtenção de informações ambientais oriundas da autoridade pública pela sociedade, independentemente de justificativa; 2) a promoção de políticas de divulgação reiterada de informações ambientais, tais como planos, estudos e relatórios ambientais.

Logo, percebe-se que o direito à informação ambiental deveria ser garantido por duas frentes de atuação estatal: a passiva e a ativa. A atuação passiva é aquela que se realiza mediante provocação da pessoa física ou jurídica, por meio do qual ela requer, de forma específica e individualizada, a informação ambiental de seu interesse. Já a atuação ativa ocorre por iniciativa do Poder Público, que possui o dever de apresentar informações ambientais gerais e relevantes para a sociedade, ainda que não haja manifestações dos indivíduos em obter tais informações. Elas seriam publicadas periodicamente, como forma de controle pela população dos avanços e das políticas exercidas pelo Estado na preservação do meio ambiente.

16 O artigo 17 da Convenção de Aarhus traz a expressa autorização para assinatura do instrumento pela União Europeia: "Artigo $17 .{ }^{\circ}$ Assinatura Esta Convenção será aberta para assinatura em Aarhus (Dinamarca) em 25 de Junho de 1998 e, posteriormente, na sede das Nações Unidas, em Nova lorque, até 21 de Dezembro de 1998 para os Estados membros da Comissão Económica para a Europa, bem como para os Estados que tenham estatuto de consultores da Comissão Económica para a Europa de acordo com os parágrafos 8 e 11 da Resolução do Conselho Económico e Social n. 36 (IV), de 28 de Março de 1947, e pelas organizações regionais de integração económica constituídas pelos Estados soberanos membros da Comissão Económica para a Europa que lhe transferiram competência para os assuntos de que trata a presente Convenção, além da competência para concluir tratados sobre essas matérias." (grifo nosso)

17 A Diretiva é uma figura legislativa do direito europeu comunitário que estabelece objetivos gerais para os Estados-membros, cabendo a cada um deles, entretanto, escolher a melhor maneira para atingi-los. (Art. 288, TFUE).

18 Conforme se depreende do $7^{\circ}$ considerando da Diretiva 2003/4/CE: "As disparidades entre as legislações em vigor nos Estados-Membros, em termos de acesso à informação sobre ambiente na posse das autoridades públicas, podem criar desigualdades no acesso a essa informação ou nas condições de concorrência, dentro da Comunidade." 
O interesse pela temática ambiental e a competência concorrente entre UE e os Estados refletiram na incorporação das proposições da Diretiva 2003/4/CE e da Convenção de Aarhus por vários países, visto que também fora estipulado prazo para a transposição ao Direito interno das disposições da Diretiva 2003/4/CE, fixado para 14 de fevereiro de 2005.

A Alemanha reeditou a sua Lei de Informação Ambiental (Umweltinformationgesetz - UIG/1994), ${ }^{19}$ em dezembro de 2004, para adequá-la às novas proposições da Convenção de Aarhus, relativas somente ao primeiro pilar - acesso à informação ambiental.

Já a Espanha publicou a Ley $27 / 2006,{ }^{20}$ nos mesmos moldes dos instrumentos internacional e supranacional, isto é, com um capítulo para cada um dos três pilares, mas com previsões específicas, como para a publicação mínima de informações pelo governo: relatórios anuais mais simplificados e relatórios quadrienais mais complexos, tanto sobre o estado do meio ambiente como sobre potenciais ameaças à saúde humana e ao meio ambiente.

Na Áustria, a Diretiva 2003/4/CE foi integrada ao sistema jurídico nacional por intermédio das alterações incluídas na Umweltinformationsgesetz des Bundes - UIG ${ }^{21}$ datada de 1993 e reformulada em 2004, que traz concepções gerais, como quais informações são passíveis de pedido pela população e quais autoridades públicas federais devem fornecê-las.

Outro importante ato legislativo emitido pela UE após a ratificação da Convenção de Aarhus, em 2005, foi o Regulamento $n^{0} 1367 / 2006^{22}$, que entrou em vigor em 28 de junho de 2007. Ele é direcionado para a própria UE, visto que especifica as obrigações contidas na Convenção de Aarhus de acesso à informação, participação popular na tomada de decisões e acesso à justiça em matéria ambiental para as suas instituições e organismos. Logo, foi necessária uma adequação jurídica para que a transposição para o âmbito comunitário das previsões da Convenção de Aarhus fossem incluídas também no Regulamento anterior. A harmonia jurídica entre os dois atos legislativos de mesma hierarquia era importante, na medida em que o Regulamento $n^{\circ} 1367 / 2006$ se tratava de norma especial, voltada para informações ambientais, o que resultou num intenso trabalho de alinhamento dele e do Regulamento $n^{\circ} 1049 / 2001$, de acesso geral aos documentos das instituições da UE (GUCKELBERGER, 2008).

O Regulamento $n^{\circ} 1367 / 2006^{23}$ inovou ao trazer a exigência de qualidade da informação ambiental, estabelecendo um mínimo a ser observado pelas autoridades públicas integrantes da União Europeia (art. $5^{\circ}$ ), bem como a não discriminação do requerente da informação ambiental em virtude de sua nacionalidade, cidadania ou domicílio, no caso de pessoa física, ou do local de estabelecimento ou atividade exercida, no caso de pessoa jurídica $\left(\right.$ art. $\left.3^{\circ}\right)$.

\section{Aplicação do direito à informação ambiental: o caso Flachglas Torgau}

Com a Diretiva 2003/4/CE, de caráter vinculante, os indivíduos e empresas começaram a solicitar informações relativas à matéria ambiental às autoridades públicas estatais. Com isso, a Convenção de Aarhus, bem como a respectiva Diretiva, foram aplicadas diretamente pelos Estados-membros, seus

19 ALEMANHA. Umweltinformationsgesetz (UIG). Disponível em: <http://www.gesetze-im-internet.de/bundesrecht/uig_2005/gesamt.pdf> Acesso em: 24 dez. 2014.

20 ESPANHA. Ley 27/2006, de 18 de julio, por la que se regulan los derechos de acceso a la información, de participación pública y de acceso a la justicia en materia de medio ambiente (incorpora las Directivas 2003/4/CE y 2003/35/CE). Disponível em: <https://www.boe.es/buscar/doc. php?id=BOE-A-2006-13010> Acesso em: 24 dez. 2014

21 ÁUSTRIA. Bundesgesetz über den Zugang zu Informationen über die Umwelt (Umweltinformationsgesetz - UIG). Disponível em: <https://www.ris. bka.gv.at/GeltendeFassung.wxe? Abfrage=Bundesnormen\&Gesetzesnummer=10010766> Acesso em: 24 dez. 2014.

22 UNIÃO EUROPEIA. Regulamento (CE) No 1367/2006 do Parlamento Europeu e do Conselho de 6 de Setembro de 2006 relativo à aplicação das disposições da Convenção de Aarhus sobre o acesso à informação, participação do público no processo de tomada de decisão e acesso à justiça em matéria de ambiente às instituições e órgãos comunitários. Jornal Oficial da União Europeia de 25 de setembro de 2006 . Disponível em: <http://eur-lex.europa.eu/legal-content/PT/TXT/HTML/?uri=CELEX:32006R1367\&from=PT> Acesso em: 20 dez. 2014.

23 Os Regulamentos são instrumentos legislativos do Direito Comunitário Europeu de caráter geral e que vinculam diretamente os Estados-Membros nos parâmetros ali estabelecidos, não Ihes sendo facultada uma margem de atuação, como no caso das diretivas. (Art. 288, TFEU). 
órgãos e pelas instituições da União Europeia na resolução de conflitos oriundos de alegadas violações aos direitos ali resguardados.

Destarte, desejável era que todos na Europa tivessem o direito à informação ambiental resguardado de modo amplo, a fim de se garantir a eficácia dos objetivos estipulados na Convenção e na Diretiva mencionadas. Todavia, as resistências encontradas para se obter as informações em matéria ambiental foram alvo de questionamentos sobre a efetivação das disposições da Diretiva, que deveria necessariamente ser comum a todos os países integrantes da União Europeia. Muitas vezes, a recusa de fornecimento foi objeto de recursos, administrativos ou judiciais, nos quais se questionava a abrangência e a interpretação das normas de Direito Comunitário.

Um interessante caso que bem exemplifica a importância que o acesso à informação ambiental adquiriu, primeiramente após a Convenção de Aarhus, mas também após a sua incorporação pelo Direito europeu, é o processo de autos C-204/09, do Tribunal de Justiça da União Europeia, envolvendo a empresa Flachglas Torgau GmbH (Flachglas) e a República Federal da Alemanha. ${ }^{24}$

A Flachglas, empresa fabricante de vidros e que participa do mercado de cotas de carbono, protocolou um pedido de informações junto ao Ministério Federal do Ambiente, da Proteção da Natureza e da Segurança Nuclear (Bundesministerium für Umwelt, Naturschutz und Reaktorsicherheit) acerca do processo legislativo da lei sobre atribuição de licenças de emissão de gases de efeito estufa. Solicitou acesso a notas e pareceres internos do referido Ministério e as comunicações com a Agência Federal do Ambiente (Umweltbundesamt).

O Ministério indeferiu o pedido, sob os argumentos de que: 1) a informação estava incluída na exclusão prevista na Convenção de Aarhus, na Diretiva 2003/4/CE e na Lei de Informação Ambiental alemã (UIG) para organismos e instituições que atuem como órgãos jurisdicionais ou legislativos; ${ }^{25} 2$ ) as informações solicitadas estariam abarcadas na hipótese de procedimentos confidenciais, cuja divulgação poderia acarretar prejuízos à sua eficácia, também consoante a legislação nos três níveis - internacional, supranacional e nacional. ${ }^{26} \mathrm{~A}$ Flachglas recorreu da decisão ao Tribunal Administrativo, com posterior recurso, tanto da empresa como do Ministério, ao Superior Tribunal Administrativo e, finalmente, ao Tribunal Administrativo Federal (última instância).

24 Em pesquisa no banco de dados HUDOC, da Corte Europeia de Direitos Humanos, a pesquisa pela expressão "Aarhus Convention" possui 12 resultados. Como exemplo, pode-se citar os casos Tatar v. Romênia (2009) e Branduse v. Romênia (2009). Disponível em: <http://hudoc.echr. coe.int/sites/eng/Pages/search.aspx\#\{“fulltext”:[“aarhus convention”],"documentcollectionid2":[“GRANDCHAMBER”,"CHAMBER"]\}> Acesso em: 17 jan. 2015.

Em pesquisa no banco de dados INFOCURIA, da Corte de Justiça da União Europeia, a pesquisa pela expressão "Aarhus Convention" possui 9 resultados. Disponível em: <http://curia.europa.eu/juris/documents.jsf?pro=\&nat=or\&oqp=\&lg=\&dates=\&language=pt\&jur=C\%2CT\%2CF\&cit=no

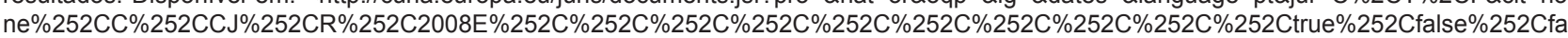
Ise\&td=\%3BALL\&text=aarhus\%2Bconvention\&pcs=Oor\&avg=\&page=1\&mat=or\&jge=\&for=\&cid=493356>Acesso em: 17 jan. 2015

25 Convenção de Aarhus: Artigo $2^{\circ}, n^{\circ}$ 2: "Autoridade pública: a) Um governo a nível nacional, regional ou outro; [...] Esta definição não inclui organismos ou instituições que atuem na qualidade de órgãos jurisdicionais ou legislativos."

Diretiva 2003/4/CE: Artigo $2^{\circ}, n^{\circ} 2$ : "Autoridade pública: a) O governo ou outros órgãos da administração pública nacional, regional ou local, incluindo órgãos consultivos; [...] Os Estados Membros podem prever que esta definição não inclua órgãos ou instituições no exercício da sua competência judicial ou legislativa. Os Estados Membros podem excluir órgãos ou instituições desta definição caso, na data de adoção da presente diretiva, a respetiva ordem constitucional não preveja um processo de recurso na acepção do artigo $6^{\circ}$." Já a Lei das informações sobre Ambiente (UIG) fixa: $\S 2, n^{\circ} 1$ : "As entidades administrativas sujeitas à obrigação de informação são: 1 . O governo e as restantes entidades administrativas públicas [ ]. Não fazem parte das entidades administrativas públicas sujeitas à obrigação de informação: a) as autoridades federais supremas que intervenham no quadro do processo legislativo ou editem decretos de aplicação [...]." (g.n.).

26 Convenção de Aarhus: Artigo $4^{\circ}, n^{\circ} 4$ : "Pode ser recusado um pedido de informações se a divulgação das mesmas afetar negativamente: a) A confidencialidade dos procedimentos das autoridades públicas, nos casos em que tal confidencialidade esteja prevista no direito interno; [...] Os fundamentos de recusa acima referidos devem ser objeto de uma interpretação restritiva, tendo em conta o interesse público defendido pela divulgação e o facto de a informação solicitada ser relativa a emissões para o ambiente." Já a Diretiva 2003/4/CE assim prevê: Artigo $4^{\circ}, \mathrm{n}^{\circ}$ 2: "Os Estados Membros podem prever o indeferimento de um pedido de informação sobre ambiente se a divulgação dessa informação prejudicar: a) A confidencialidade dos procedimentos das autoridades públicas, quando tal confidencialidade esteja prevista por lei;"

UIG: $\S 8, n{ }^{\circ} 1$ : "Quando a divulgação das informações prejudicar [...] 2. a confidencialidade dos procedimentos das autoridades sujeitas à obrigação de informação na acepção do $\S 2, n^{\circ} 1 ;[\ldots]$ o pedido deve ser indeferido, a menos que um interesse superior justifique a divulgação [...]." (g.n.). 
Antes de decidir, entretanto, o processo original BVerwG 7 C 17.08, o Tribunal Administrativo Federal teve um pedido de reenvio prejudicial, ${ }^{27}$ direcionado ao Tribunal de Justiça da União Europeia e admitido em 8 de junho de 2009, por meio do qual solicitou a intepretação de dispositivos da Diretiva 2003/4/CE mediante a formulação das seguintes questões prejudiciais:

\section{Questões prejudiciais}

1. a) $\mathrm{O}$ artigo $2^{\circ}$, ponto 2 , segundo parágrafo, primeiro período, da Diretiva 2003/4/CE do Parlamento Europeu e do Conselho, de 28 de Janeiro de 2003, relativa ao acesso do público às informações sobre ambiente e que revoga a Diretiva 90/313/CEE do Conselho (1), deve ser interpretado no sentido de que só atuam no exercício da sua competência legislativa os órgãos e as instituições a quem, segundo a legislação do Estado-Membro em causa, compete tomar a decisão final (vinculativa) no processo legislativo, ou também atuam no exercício da competência legislativa os órgãos e as instituições a quem a legislação desse Estado confiou competências e direitos de participação no processo legislativo, em especial para apresentar projetos de lei e para emitir pareceres sobre estes projetos?

b) Os Estados-Membros só podem prever que a definição do conceito de autoridade pública não abrange órgãos e instituições no exercício da sua competência judicial ou legislativa caso, na data da adoção da Diretiva 2003/4/CE do Parlamento Europeu e do Conselho, de 28 de Janeiro de 2003, relativa ao acesso do público às informações sobre ambiente e que revoga a Diretiva 90/313/CEE do Conselho, a respectiva ordem constitucional não previsse um processo de recurso na acepção do artigo $6^{\circ}$ da mesma diretiva?

c) Os órgãos e as instituições no exercício da competência legislativa só não estão abrangidos pelo conceito de autoridade pública até à conclusão do processo legislativo?

2. a) A confidencialidade dos procedimentos está prevista na lei - na acepção do artigo $4^{\circ}$, n. 2 , primeiro parágrafo, alínea a), da Diretiva 2003/4 do Parlamento Europeu e do Conselho, de 28 de Janeiro de 2003, relativa ao acesso do público às informações sobre ambiente e que revoga a Diretiva 90/313/CEE do Conselho - quando a disposição de direito nacional adotada para transpor esta diretiva determina, em termos gerais, que o pedido de acesso a informações sobre o ambiente deve ser indeferido quando a divulgação das informações prejudique a confidencialidade dos procedimentos dos órgãos públicos sujeitos a uma obrigação de informação, ou é necessário que uma disposição legislativa especial prescreva a confidencialidade dos procedimentos?

b) A confidencialidade dos procedimentos está prevista na lei - na acepção do artigo $4^{\circ}, \mathrm{n}$. 2, primeiro parágrafo, alínea a), da Diretiva 2003/4/CE do Parlamento Europeu e do Conselho, de 28 de Janeiro de 2003, relativa ao acesso do público às informações sobre ambiente e que revoga a Diretiva 90/313/CEE do Conselho - quando existe no direito nacional um princípio geral não positivado que impõe a confidencialidade dos procedimentos administrativos das autoridades públicas? (UNIÃO EUROPEIA, 2009, p. 11-12).

Os pedidos de interpretação direcionados ao Tribunal de Justiça da União Europeia são enviados pelos Tribunais nacionais, os quais são responsáveis pela aplicação do Direito europeu no âmbito interno dos Estados-membros. No intuito de uniformizar a intepretação dos mesmos dispositivos de Direito Comunitário pelos Tribunais, o Tribunal de Justiça da União Europeia pode determinar qual a interpretação adequada e que deverá ser observada por eles, principalmente quando existir dúvida em relação à interpretação ou validade da norma de Direito europeu. Após a tramitação do procedimento de reenvio prejudicial, é emitido um parecer denominado "decisão de questão prejudicial".

Das questões prejudiciais apresentadas ao Tribunal de Justiça da União Europeia, depreendem-se as dúvidas de intepretação que, para o caso em comento, seriam de grande relevância para o desfecho da demanda. A primeira questão faz referência às exceções relativas à obrigação da autoridade pública fornecer as informações pretendidas. Nos três níveis de legislação aplicáveis ao caso - internacional

27 O reenvio prejudicial é um recurso indireto apresentado ao Tribunal de Justiça da União Europeia, cujo objetivo é o alinhamento de entendimentos e aplicação de leis europeias pelos tribunais nacionais. Há um requerimento do tribunal nacional pela interpretação de determinado ato normativo comunitário, que após a resposta será utilizado para a resolução do litígio. Portanto, não cabe ao Tribunal de Justiça da União Europeia decidir sobre a demanda, mas sim evitar a aplicação diferenciada de um mesmo dispositivo pelos tribunais nacionais. Sobre os possíveis recurssos ao Tribunal de Justiça da União Europeia, veja Mata Diz (2005). 
(Convenção de Aarhus), supranacional (Diretiva 2003/4/CE) e nacional (UIG) -, há expressa menção de que órgãos e instituições que atuem em processos legislativos ou jurisdicionais não estão incluídos no conceito de "autoridade pública". Entretanto, a dúvida recai sobre o alcance da expressão para os casos em que o Poder Executivo apenas apresenta projetos de lei e faz pareceres sobre os temas da novel legislação.

Esse é o caso do Ministério do Ambiente alemão em relação à lei sobre atribuição de licenças de emissão de gases de efeito estufa, a respeito da qual a Flachglas pretendia obter informações. $O$ Ministério considerou que, ao participar de um processo legislativo, não como detentor da decisão final de elaboração da lei ou sua promulgação, mas apenas incumbido da iniciativa de apresentar o projeto ao Parlamento alemão, estaria abarcado pela exceção prevista nas normas internacional, europeia e nacional. Também se questionou a abrangência temporal da exceção prevista em lei: se ela seria válida apenas durante o processo legislativo ou vigoraria também após o seu término, com a promulgação da lei. Isso porque o pedido formulado pela Flachglas ocorreu após o término do procedimento de elaboração e promulgação da lei, de modo que, no seu entendimento, o Ministério do Ambiente não exerceria mais atividades relacionadas ao processo legislativo quanto àquela lei em específico.

A segunda parte do questionamento realizado pelo Tribunal Administrativo Federal ao Tribunal de Justiça da União Europeia refere-se à confidencialidade dos procedimentos, justificativa utilizada pelo Ministério do Ambiente para indeferir o pedido de informações protocolado. Adúvida é se a confidencialidade, quando da transposição da norma europeia para o Direito interno, pode ser uma regra geral ou deverá ser especificada na legislação nacional, bem como o conceito de "procedimento administrativo de autoridades públicas", sobre o qual essa previsão de confidencialidade recairia.

Com a interpretação feita pelo Tribunal de Justiça da União Europeia, o Tribunal Administrativo Federal poderia então julgar a causa, na medida em que se julgaria se a recusa do Ministério do Ambiente ocorreu legalmente ou se extrapolou as previsões das legislações sobre acesso à informação ambiental, o que representaria uma violação ao direito assegurado da Flachglas, bem como um desvio dos objetivos de transparência e participação popular elencados na Convenção e na Diretiva.

A advogada-geral, Eleanor Sharpston, apresentou suas conclusões em 22 de junho de 2011, na qual afirmou que entende que as exceções ao acesso à informação ambiental devem ser interpretadas de forma restritiva. Em relação à primeira questão, acerca da possibilidade de que órgãos administrativos sejam incluídos na exceção à obrigação de prover informações ambientais, ao analisar que "o poder executivo [alemão] é [...] o principal detentor da iniciativa legislativa no parlamento federal [...] [e] durante o procedimento de adoção de um projeto-lei no órgão legislativo, o Ministério pode ser consultado e emitir pareceres" (Processo C-204/09, apartado 46), entendeu-se que houve, no caso em comento, uma participação no processo legislativo que autorizaria a inclusão do Ministério do Ambiente na exceção prevista nas legislações aplicáveis.

Entretanto, a fim de se promover o direito à informação ambiental, concluiu-se que tal prerrogativa deve ser exercida somente durante o processo legislativo. Isso porque a exceção possui como objetivo resguardar a imparcialidade e a celeridade de processos legislativos e jurisdicionais, que poderiam ser afetados quando "dos insistentes pedidos de informações, da contestação veemente das informações obtidas e das tentativas persistentes de influenciar o resultado com base nessas informações" (Processo C-204/09, apartado 52), na medida em que ainda estão sendo utilizados para a elaboração de normas ou julgados. Assim, em resposta à primeira questão, a advogada-geral entendeu que a exclusão dos órgãos do Poder Executivo que atuem com competência legislativa deveria se limitar ao período compreendido entre o início e o fim do procedimento em questão, e assim sugeriu

Proponho, assim, a resposta à alínea a) da primeira questão submetida pelo órgão jurisdicional de reenvio no sentido de que, nos termos do artigo $2 .^{\circ}, \mathrm{n} .^{\circ} 2$, segunda frase, da diretiva, os órgãos do executivo que, no contexto jurídico e constitucional do respetivo Estado Membro, desempenham um papel no processo legislativo limitado à apresentação de propostas 
legislativas ou à formulação de observações sobre estas podem ser excluídos da definição de «autoridade pública» quando desempenham esse papel. (Processo C-204/09, apartado 63, grifo nosso).

A segunda questão enviada pelo Tribunal Administrativo Federal alemão dizia respeito à necessidade de previsão legal específica a respeito da confidencialidade das informações ambientais. Primeiramente, o conceito de "procedimentos das autoridades públicas" foi analisado a fim de delimitar quais atividades realizadas no âmbito da Administração são passíveis de serem objeto de pedidos sobre informações ambientais. Ocorre que, em seu pedido, a Flachglas solicitou as comunicações trocadas entre o Ministério do Ambiente e a autoridade federal competente em matéria de comércio de licenças de emissão.

Em suas conclusões, a advogada-geral entendeu que procedimentos são manifestações de opinião e discussões de opções políticas, em um contexto de tomada de decisão por parte de uma autoridade. Logo, as mensagens trocadas entre autoridades públicas não estariam abarcadas no conceito de procedimentos e, por isso, não poderiam ser alvo de pedidos de informação, nos moldes previstos na Convenção de Aarhus, da Diretiva 2003/4/CE e da UIG.

Com isso, não haveria o que se falar em confidencialidade das comunicações, visto que elas não são procedimentos de acordo com as legislações referentes ao acesso à informação ambiental. Entretanto, prosseguindo na discussão acerca da previsão legal específica ou apenas geral sobre a confidencialidade, mais uma vez a interpretação foi restritiva, de modo a garantir o maior acesso à informação ambiental possível.

No intuito de evitar decisões arbitrárias por parte do Poder Público e viabilizar o direito fundamental ancorado nas referidas normas, baseando-se no princípio da segurança jurídica, a advogada-geral entendeu que a expressão "prevista por lei" corresponde à necessidade de não se fornecer uma margem de discricionariedade à autoridade requisitada. Se para tanto basta uma regra geral, ou é indispensável a previsão legal específica, tal contexto deve ser analisado pelos Tribunais nacionais. Desse modo, assim conclui a advogada-geral a respeito da segunda questão

Considero, portanto, que o critério previsto no artigo $4^{\circ}, n^{\circ} 2$, alínea a), só é cumprido quando um princípio jurídico geral não escrito nos termos do qual os procedimentos administrativos das autoridades públicas não são públicos implica, de forma clara e inequívoca, uma obrigação de confidencialidade no que diz respeito a esses procedimentos e não deixa à autoridade pública em causa qualquer margem de discricionariedade relativamente à confidencialidade (Processo C-204/09, apartado 99, grifo nosso).

O acórdão do Tribunal de Justiça da União Europeia, datado de 14 de fevereiro de 2012, acatou in totum as conclusões da advogada-geral, além de fazer suas próprias ponderações, necessárias para a adequada interpretação dos dispositivos legais relacionados nas questões prejudiciais. Foi explicitado, por exemplo, que tal interpretação se restringia a processos legislativos propriamente ditos, e não a procedimentos que resultem em normas hierarquicamente inferiores a leis.

Ademais, ressaltou que uma das funções dos ministérios, entre outras, é a de elaborar projetos de lei, apresentá-los ao Parlamento e participar do procedimento legislativo mediante a redação de pareceres sobre a matéria versada. Assim, correto seria o entendimento de que, enquanto agindo nesta função, órgãos do Poder Executivo estariam incluídos na previsão legal que exclui do conceito de autoridade pública os órgãos e instituições com competência legislativa.

O Plenário do Tribunal também compartilhou da alegação de que tal prerrogativa finda-se com a promulgação da lei, uma vez que ocorre o término do procedimento legislativo. Dessa maneira, não haveria mais o fundamento da exclusão supramencionada, qual seja, evitar a interferência na elaboração e formulação das leis.

No que diz respeito à questão da confidencialidade e sua expressa menção no Direito nacional, o Tribunal aplicou $\mathrm{o}$ art. $288,3^{\circ} \S$, da TFUE. Tal dispositivo prescreve a faculdade dos Estados-membros 
de escolherem os meios e formas a serem utilizados para a transposição das Diretivas, sendo inclusive desnecessária a iniciativa legislativa por parte de cada governo, desde que a norma supranacional tenha vigência e eficácia no Direito interno. Entretanto, a expressão "previsto no direito interno", constante no art. $4^{\circ}$, n. 4, da Convenção de Aarhus, pressupõe a existência, no Direito nacional, de uma norma expressa, e não apenas um contexto jurídico abarcado por previsão geral. A confidencialidade das informações ambientais deveria estar prevista expressamente no ordenamento.

Desse modo, concluiu o Tribunal de Justiça da União Europeia que, primeiramente, o legislador interno deve esclarecer qual o conceito de "procedimento", a fim de que a ressalva de confidencialidade seja oponível, bem como a verificação da interpretação do conceito pelo juiz nacional. Com essa determinação clarificada no sistema jurídico nacional, a confidencialidade, então, poderá ser disposta em norma geral, na medida em que a restrição à discricionariedade do agente público estará resguardada pela delimitação dos procedimentos cujas informações podem ser consideradas confidenciais. Logo, assim foi decidido o processo

1) $O$ artigo $2^{\circ}$, n. 2, segundo parágrafo, primeiro período, da Diretiva 2003/4/CE do Parlamento Europeu e do Conselho, de 28 de janeiro de 2003, relativa ao acesso do público às informações sobre ambiente e que revoga a Diretiva 90/313/CEE do Conselho, deve ser interpretado no sentido de que a faculdade concedida por esta disposição aos Estados Membros de não considerarem como autoridades públicas os «órgãos ou instituições no exercício da sua competência [...] legislativa» pode ser aplicada aos ministérios na medida em que participem no processo legislativo, nomeadamente através da apresentação de projetos de lei ou de pareceres, e que essa faculdade não está subordinada ao respeito das condições enunciadas no artigo $2^{\circ}$, n. 2 , segundo parágrafo, segundo período, desta diretiva.

2) $O$ artigo $2^{\circ}$, n. 2, segundo parágrafo, primeiro período, da Diretiva 2003/4 deve ser interpretado no sentido de que a faculdade concedida por esta disposição aos Estados Membros de não considerarem autoridades públicas os órgãos e as instituições no exercício da sua competência legislativa deixa de poder ser exercida quando o processo legislativo em causa tenha terminado.

3) $O$ artigo $4^{\circ}$, n. 2, primeiro parágrafo, alínea a), da Diretiva 2003/4 deve ser interpretado no sentido de que a condição nele prevista de a confidencialidade dos procedimentos das autoridades públicas estar prevista por lei pode ser considerada preenchida quando exista, no direito nacional do Estado Membro em causa, uma disposição nos termos da qual, de um modo geral, a confidencialidade dos procedimentos das autoridades públicas constitui um fundamento de recusa de acesso a informações sobre ambiente na posse dessas autoridades, desde que o direito nacional determine claramente o conceito de procedimento, o que cabe ao juiz nacional verificar.

O caso Flachglas não foi o primeiro no Tribunal de Justiça da União Europeia que tratou da Convenção de Aarhus a respeito do direito fundamental à informação ambiental; ${ }^{28}$ entretanto, foi o primeiro a ser julgado pelo Plenário, o que ocorre quando um Estado-membro ou uma instituição da União for parte na instância que solicitar a manifestação do Tribunal, consoante o art. 16, parte 3, do Estatuto do Tribunal de Justiça da União Europeia. A Grande Seção é composta por 15 (quinze) juízes, sendo que a decisão deverá ser proferida por no mínimo 11 (onze) juízes (MATA DIZ; OLIVEIRA, 2010). O caso em comento, portanto, possui grande repercussão, tanto no que tange a sua abrangência como a sua importância, na medida em que representa uma interpretação de importantes dispositivos da Diretiva 2003/4/CE e da Convenção de Aarhus.

O direito fundamental ao acesso à informação ambiental restou resguardado, visto que as limitações previstas pela legislação foram interpretadas de forma restritiva, prevalecendo o interesse público na publicação dos documentos. Apesar de a disposição acerca da confidencialidade ter sido deixada a cargo dos Estados-membros em suas legislações nacionais, o que poderia acarretar graus diversos de entendimento sobre esse fundamento de recusa pelo Poder Público, o entendimento do Tribunal de que a

28 A Quarta Seção tratou do conceito de "informação sobre ambiente" no processo C266/09, julgado em 16 de dezembro de 2010 . A respeito do Regulamento $n^{\circ} 1367 / 2006$, podemos citar os seguintes julgados: T29/08, T264/04, todos analisados por seções do Tribunal de Justiça da União Europeia. 
discricionariedade deve ser evitada foi correta, pois a autoridade pública deve estar vinculada à obrigação de prestar informações sempre que possível para promover a transparência e o direito assegurado à população de modo geral.

\section{Conclusão}

O acesso à informação como instrumento essencial para a concretização do exercício do direito à participação deve ser analisado não só por sua natureza de direito fundamental, mas também pela própria vinculação com a democracia e a participação popular direta no processo de tomada de decisão. As questões determinantes para fixar o conteúdo, abrangência e interpretação desse direito supõem uma atuação concreta não só dos poderes estatais, mas também das organizações internacionais e de integração regional que trabalham em prol da promoção do desenvolvimento sustentável.

Nesse sentido, o presente trabalho buscou analisar a regulação do direito à participação, em especial no que se refere ao acesso à informação, considerada o primeiro pilar da proteção ambiental, conforme analisado anteriormente no marco da Convenção de Aarhus, bem como sua incorporação e aplicação pelo Direito europeu. A importância deste instrumento internacional pode ser dimensionada a partir justamente da interpretação dada pelo Tribunal de Justiça da UE no caso examinado no presente artigo, além das disposições inovadoras que criam obrigações diretas para o exercício da participação em matéria ambiental.

A criação de um ato internacional consubstanciado na forma de uma Convenção pode representar também um passo importante na configuração dos sistemas nacionais ao permitir que os efeitos surgidos a partir de sua aplicação pelos órgãos nacionais e internacionais possam impactar o sistema interno, de modo direto - por meio da incorporação - ou indireto - mediante a absorção de temas relevantes para a agenda ambiental. Nesse caso, por exemplo, mesmo que um país não tenha firmado e incorporado a Convenção, ele pode regular a matéria mediante a criação de instrumentos legais internos que venham a espelhar as disposições convencionais. Portanto, a Convenção de Aarhus pode ser considerada um referencial para a garantia do direito à participação e o acesso à informação, maxime quando relacionada com a proteção ambiental.

Finalmente, o acesso à informação como corolário da participação merece ser objeto de atenção por parte dos Estados, visto que estabelece os pressupostos para o exercício da cidadania, o fortalecimento da democracia e a participação da sociedade nos processos de tomada de decisão. O direito de ser informado e de influenciar diretamente nas decisões em matéria ambiental apresenta-se como fundamento de um Estado comprometido com o desenvolvimento sustentável e o meio ambiente ecologicamente equilibrado. Não pode o indivíduo ser privado de conhecer, conscientizar-se e decidir sobre questões afetas à sua própria vida; é neste sentido que deve ser interpretado e aplicado o direito à participação.

\section{Referências}

AMADO, Carla Gomes. A caminho de uma ecocidadania. Notas sobre o direito à informação ambiental. In: NERY JUNIOR, Nelson; NERY, Rosa Maria de Andrade (Org.). Responsabilidade civil: direito à informação. São Paulo: Revista dos Tribunais, 2010. v. 8. p. 221-248.

BONAVIDES, Paulo. Curso de direito constitucional. 22. ed. São Paulo: Malheiros, 2007.

BONDIA, Alfonso González. La regulación comunitaria europea del acceso a la información, la participación pública y el acceso a la justicia en materia de medio ambiente en sus estados miembros.In: SOLÉ, Antoni Pigrau (Org.). Acceso a la información, participación pública y acceso a la justicia en materia de medio ambiente: diez años del Convenio de Aarhus. Barcelona: Atelier, 2008. 
Comunidade Europeia em matéria de ambiente a ambiente 2010: o nosso futuro, a nossa escolha - Sexto Programa de Acção em matéria de Ambiente. Disponível em: <http://eur-lex.europa.eu/legalcontent/pt/txt/html/?uri=celex:52001d c0031\&from=PT>. Acesso em: 25 abr. 2015.

DUVIC-PAOLI, Leslie-Anne. The status of the right to public participation in international environmental law: an analysis of the jurisprudence. Yearbook of International Environmental Law, Oxford, v. 23, n. 1, p. 80-105, 2012.

GUCKELBERGER, Annette. Die EG-verordnung zur umsetzung der aarhus-konvention auf der gemeinschaftsebene. Natur und Recht, Tübingen, v. 30, 2008.

GUSTIN, Miracy Barbosa de Sousa; DIAS, Maria Teresa Fonseca. (Re)pensando a pesquisa jurídica. 2. ed. Belo Horizonte: Del Rey, 2006.

LIZARRAGA, José Antonio Rasquin; ESPINOSA, Angel María Ruiz de A. Información, participación y justicia en materia de medio ambiente: comentario sistemático a la Ley 27/2006, de 18 de julio. Madrid: Thomson-Aranzadi, 2007.

MACHADO, Paulo Affonso Leme. Direito à informação e meio ambiente. São Paulo: Malheiros, 2006.

MATA DIZ, Jamile Bergamaschine. La importancia del Tribunal de Justicia de las Comunidades Europeas en la construcción del derecho comunitario: el caso de la sentencia "Centros". Revista Jurídica (FURB), Santa Catarina, v. 18, p. 241-271, 2005.

MATA DIZ, Jamile Bergamaschine; DISCACCIATI, Ana Clara Gonçalves. Acesso à informação ambiental: por um novo paradigma de participação. Revista Direito e Liberdade, Natal, v. 17, n. 3, p. 71-113, set./ dez. 2015.

MATA DIZ, Jamile Bergamaschine; GOULART, Rayelle Campos Caldas. A aplicação do princípio da integração ambiental nas políticas setoriais Europeias. In: SAMYRA, Haydëe Dal; FARRA NASPOLINI SANCHES, Carlos André; BIMFELD, Luiz Ernani Bonesso (Org.). Direito e sustentabilidade.

Florianópolis: FUNJAB, 2013.

MATA DIZ, Jamile Bergamaschine; OLIVEIRA, Paulo César P. O papel do Tribunal de Justiça da União Europeia na construção do direito comunitário e no fortalecimento do direito fundamental do acesso à justiça comunitária. In: SALIBA, Aziz Tuffi; ALMEIDA, Gregório Assagra de; GOMES JÚNIOR, Luiz Manoel (Org.). Direitos fundamentais e a função do Estado nos planos internos e internacionais. Belo Horizonte: Arraes, 2010.

MOLINA DEL POZO, Carlos Francisco; MATA DIZ, Jamile Bergamaschine. La distribución de competencias en el nuevo diseño de la Unión Europea: del Acta Única Europea al Tratado de Lisboa.

Revista de la Facultad de Derecho y Ciencias Políticas - Universidad Pontificia Bolivariana, Medellín, v. 43, n. 118, p.15-59, jan./jun. 2013.

NASSER, Salem Hikmat. Fontes e normas do direito internacional: um estudo sobre a soft law. 2. ed. São Paulo: Atlas, 2006.

PASTOR, Aitana de la Varga; FUENTES i GASÓ, Josep Ramon. Las autoridades públicas ante las nuevas obligaciones en materia de información ambiental. Especial referencia a la difusión de información ambiental. In: SOLÉ, Antoni Pigrau (Org.). Acceso a la información, participación pública y acceso a la justicia en materia de medio ambiente: diez años del Convenio de Aarhus. Barcelona: Atelier, 2008. p. 187-224.

SAMPAIO, José Adércio Leite; WOLD, Chris; NARDY, Afrânio José Fonseca. Princípios de direito ambiental. Belo Horizonte: Del Rey, 2003.

SCHLACKE, Sabine; SCHRADER, Christian; BUNGE, Thomas. Informationsrechte, öffentlichkeitsbeteiligung und rechtsschutz im umweltrecht: Aarhus-Handbuch. Berlin: Erich Schmidt Verlag GmbH \& Co., 2009.

SOLÉ, Antoni Pigrau; PENTINAT, Susana Borràs. Diez años del Convenio de Aarhus sobre el acceso a la información, la participación y el acceso a la justicia en materia de medio ambiente. In: SOLÉ, Antoni 
Pigrau (Org.). Acceso a la información, participación pública y acceso a la justicia en materia de medio ambiente: diez años del Convenio de Aarhus. Barcelona: Atelier, 2008. p. 21-84.

UNIÃO EUROPEIA. Jornal Oficial da União Europeia $n^{\circ} \mathrm{C} 193,15$ ago. 2009. p. 11-12. Disponível em: <http://eur-lex.europa.eu/legal-content/pt/TXT/PDF/?uri=uriserv\%3AOJ.C_.2009.193.01.0011. 01.POR>. Acesso em: 27 dez. 2014.

UNITED NATIONS ECONOMIC COMMISSION FOR EUROPE. The Aarhus Convention: an implementation guide. 2. ed. 2012. Disponível em: <http://www.unece.org/fileadmin/DAM/env/pp/ Publications/Aarhus_Implementation_Guide_interactive_eng.pdf> Acesso em: 07 jan. 2015.

UNITED STATES OF AMERICA. Environmental Protection Agency (EPA). Disponível em: <http://www. epa.gov/oecaerth/environmentaljustice/basics/index.html> Acesso em: 27 jan. 2015.

AGRADECIMENTO: A autora agradece ao Programa Eramus +, Cátedra Jean Monnet de Direito da UFMG (565401-EPP-1-2015-1-BREPPJMO-CHAIR), pelo apoio concedido, e à Fundação de Amparo à Pesquisa do Estado de Minas Gerais (FAPEMIG), ante o financiamento para projeto de pesquisa APQ00369-13.

Recebido em: 10/07/2015

Aprovado em: 11/05/2017 